\title{
A label-free electrochemical assay for coronavirus IBV H120 strain quantification based on equivalent substitution effect and AuNPs-assisted signal amplification
}

\author{
Yazhi Yang ${ }^{1} \cdot$ Dawei Yang ${ }^{2} \cdot$ Yingge Shao $^{1} \cdot \mathrm{Yi} \mathrm{Li}^{1} \cdot$ Xifeng Chen $^{2} \cdot$ Yuanyuan $\mathrm{Xu}^{1}$ (D) $\cdot$ Jinfeng Miao ${ }^{1}$
}

Received: 2 June 2020 / Accepted: 29 September 2020 / Published online: 23 October 2020

(C) Springer-Verlag GmbH Austria, part of Springer Nature 2020

\begin{abstract}
A label-free electrochemical strategy is proposed combining equivalent substitution effect with AuNPs-assisted signal amplification. According to the differences of S1 protein in various infectious bronchitis virus (IBV) strains, a target DNA sequence that can specifically recognize H120 RNA forming a DNA-RNA hybridized double-strand structure has been designed. Then, the residual single-stranded target DNA is hydrolyzed by S1 nuclease. Therefore, the content of target DNA becomes equal to the content of virus RNA. After equivalent coronavirus, the target DNA is separated from DNA-RNA hybridized double strand by heating, which can partly hybridize with probe 2 modified on the electrode surface and probe 1 on AuNPs' surface. Thus, AuNPs are pulled to the surface of the electrode and the abundant DNA on AuNPs' surface could adsorb a large amount of hexaammineruthenium (III) chloride (RuHex) molecules, which produce a remarkably amplified electrochemical response. The voltammetric signal of RuHex with a peak near $-0.28 \mathrm{~V} \mathrm{vs.} \mathrm{Ag} / \mathrm{AgCl}$ is used as the signal output. The proposed method shows a detection range of $1.56 \mathrm{e}^{-9}$ to $1.56 \mathrm{e}^{-6} \mu \mathrm{M}$ with the detection limit of $2.96 \mathrm{e}^{-10} \mu \mathrm{M}$ for IBV H120 strain selective quantification detection, exhibiting good accuracy, stability, and simplicity, which shows a great potential for IBV detection in vaccine research and avian infectious bronchitis diagnosis.
\end{abstract}

Keywords Coronavirus · IBV H120 strain · Equivalent substitution effect · AuNPs-assisted signal amplification · Electrochemical assay

Yazhi Yang and Dawei Yang contributed equally to this work.

Electronic supplementary material The online version of this article (https://doi.org/10.1007/s00604-020-04582-3) contains supplementary material, which is available to authorized users.

Yuanyuan $\mathrm{Xu}$

xuyuanyuan@njau.edu.cn

Jinfeng Miao

mjf171647@126.com

1 MOE Joint International Research Laboratory of Animal Health and Food Safety, Key Laboratory of Animal Physiology \& Biochemistry, College of Veterinary Medicine, Nanjing Agricultural University, Nanjing 210095, China

2 Suzhou Institute of Biomedical Engineering and Technology, Chinese Academy of Sciences, Suzhou 215163, China

\section{Introduction}

In the last few decades, viruses are a real menace to safety. The pandemic dimension spread of coronavirus disease poses a severe threat to the health and lives of seven billion people worldwide [1]. Rapid identification of viruses should be one of the best ways to prevent disease outbreaks and is of great significance to medical healthcare [1]. IBV, one kind of coronaviruses, is a positive-sense single-stranded enveloped RNA virus with a length of $27-32 \mathrm{~kb}$. One IBV strain, H120 strain, usually needs to be identified from other strains for immunoprophylaxis and vaccine production, for example, NNA strain. Both of them are composed of structural and nonstructural proteins $[2,3]$. The spike (S) glycoprotein is one of the major structural proteins which can be posttranslationally cleaved into S1 and S2 subunits [4]. S1 subunit determines the genotype, serotype, and phenotype of IBV, which is the most significant protein for virus identification [5]. It is known that gene sequences of H120 and NNA strains 
are highly similar [6-8]; as a result, an obstacle in immunoprophylaxis presents because of the lack of accurate identification method. Therefore, developing a rapid and sensitive method for identification and quantification of different IBV strains based on hypervariable region of S1 gene can effectively solve the problem, which plays important roles in IB early diagnosis and control, especially for vaccine production.

Up to now, a number of methods have been fabricated to diagnose acute IBV infections based on IBV virus RNA detection and antibody response. These common methods include immunofluorescence assay (IFA) [9], agar gel precipitation test (AGPT) [10], virus isolation (VI) [11], immunoperoxidase assay (IPA) [12], reverse transcriptase polymerase chain reaction (RT-PCR) [13], and enzyme-linked immunosorbent assay (ELISA) [4]. Among the above methods, the sensitivity is generally unsatisfactory and those methods are relatively expensive and laborious. Meanwhile, one of present challenges in the virus detection field is the need for further non cross-reactive, stable, and sensitive biosensors [14]. Thus, the development of ultrasensitive and fast methods to detect IBV is still a great challenge and absolutely necessary. To improve the sensitivity, the signal amplification strategy should be utilized $[15,16]$.

Recently, some studies have shown that nanomaterials play an essential role in nanotechnology and biomedical applications $[17,18]$. Among different nanomaterials, gold nanoparticles (AuNPs) have attracted tremendous interests [19, 20], due to its characteristics including easy synthesis manipulation, precise control over the physicochemical properties, strong binding affinity for thiols, and distinct electronic properties [21]. AuNPs have been used as efficient sensors for the detection of DNA and RNA based on different sensing strategies $[22,23]$. Among the electrochemical methods, it has attracted great attention due to its properties [24, 25], including convenient operability, simple instrumentation, low cost, and on-site detection [26, 27]. Thus, the development of labelfree electrochemical biosensor for the assay of IBV detection based on the AuNPs amplification is very promising.

\section{Experimental section}

\section{Materials and apparatus}

AL2000 DNA marker and $1 \mathrm{~kb}$ DNA Ladder marker were obtained from Nanjing Zhongding Biotechnology Co. Ltd. Prime Script II 1st Strand cDNA Synthesis Kit, SYBR Premix Ex Taq II (Tli RNaseH Plus) Bulk, pMD19-T Vector Cloning Kit, and EcoRI were purchased from Dalian Bao Biological Engineering Co. Ltd. The AxyPrep DNA Gel Extraction Kit was obtained from Axygen (USA). Chloroauric acid, sodium citrate, and tris(2-carboxyethyl)-phosphine
(TCEP) were purchased from Sigma-Aldrich Chemical Co. Ltd. (USA). Other reagents in the method were of analytical grade. All solutions in the study were prepared with ultrapure water, which was obtained from Milli Q water purification system (USA).

The DNA immobilization buffers are $10 \mathrm{mM}$ Tris- $\mathrm{HCl}$, $1 \mathrm{mM}$ EDTA, $0.1 \mathrm{M} \mathrm{NaCl}$, and $10 \mu \mathrm{M}$ TCEP (pH 7.4). The reaction buffer is phosphate-buffered saline $(10 \mathrm{mM}$ $\left.\mathrm{Na}_{2} \mathrm{HPO}_{4}, 2 \mathrm{mM} \mathrm{NaH} \mathrm{PO}_{4}, \mathrm{pH} 7.4\right)$ with $140 \mathrm{mM} \mathrm{NaCl}$ and $5 \mathrm{mM} \mathrm{MgCl}_{2}$. DNA oligonucleotides (HPLC purified) were synthesized by Sangon Biotechnology Co. Ltd. (Shanghai, China). All the electrochemical measurements were performed on $\mathrm{CHI}$ 660D electrochemical workstation (Shanghai, China). DNA sequences used in this electrochemical assay were shown in Table 1.

\section{IBV RNA extraction and S1 gene amplification}

The AxyPrep Body Fluid Viral DNA/RNA Miniprep Kit was used to extract viral RNA. The Prime Script II 1st Strand cDNA Synthesis Kit and Roche's PCR enzyme FastStart Universal SYBR Green Master (ROX) were for RNA inversion and $\mathrm{S} 1$ gene amplification, respectively. The $\mathrm{S} 1$ gene amplification reaction system (total volume $25 \mu \mathrm{L}$ ) contained $12.5 \mu \mathrm{L}$ of $2 \times$ PCR Master Mix, $1 \mu \mathrm{L}$ of cDNA products, $9.5 \mu \mathrm{L}$ of $\mathrm{ddH}_{2} \mathrm{O}$, and $1 \mu \mathrm{L}$ of 10 pmol of S1 forward and $\mathrm{S} 1$ reverse primer (Table S1). Amplification procedures were as follows: $95^{\circ} \mathrm{C}$ for $5 \mathrm{~min}$, then 33 cycles of $95^{\circ} \mathrm{C}$ for $30 \mathrm{~s}$, $52{ }^{\circ} \mathrm{C}$ for $30 \mathrm{~s}, 72{ }^{\circ} \mathrm{C}$ for $1 \mathrm{~min}$, and finally $10 \mathrm{~min}$ at $72^{\circ} \mathrm{C}$. The products were electrophoresed on a $2 \%$ agarose gel and stained with ethidium bromide.

\section{Construction of standard plasmid}

After purification, PCR product was connected with pMD19T. Then, it was transformed into susceptible $E$. coli by conventional method and coated on plates with ampicillin and LB. White colonies were selected and inoculated in LB medium containing ampicillin. Finally, the plasmids were extracted for sequencing and identification by enzyme digestion. The concentration of standard plasmids was measured by ultraviolet spectrophotometer and copy number was calculated through the equation: copies $/ \mathrm{mL}=$ plasmid concentration $\times$ $6.02 \times 10^{23} \times 10^{-9} /($ plasmid length $\times 660)$. After

Table 1 List of DNA sequences used in this experiment

\begin{tabular}{ll}
\hline Name & Sequence $\left(5^{\prime}-3^{\prime}\right)$ \\
\hline SH-H120-Probe1 & TTT TTT TCA GGT GAG TTA \\
H120-Probe 2-SH & GAT CAT AAT ATA TAT ATA T \\
H120-Target & ATT ATG ATC TAA CTC ACC TGA \\
\hline
\end{tabular}


determination of copy number, a series of standard plasmids at different copies were prepared for real-time fluorescence quantitative PCR to obtain the standard linear curve, which was used to calculate the concentration of real virus samples.

\section{Preparation of probe 1-functionalized AuNPs}

The synthesis of AuNPs was according to our previous report [28]. Then, $100 \mu \mathrm{L}$ of AuNPs colloid was incubated with $40 \mu \mathrm{L}$ of $10 \mu \mathrm{M}$ probe 1 and $360 \mu \mathrm{L}$ of PBS buffer. The mixed solution was oscillated slowly in $37^{\circ} \mathrm{C}$ for $12 \mathrm{~h}$. After that, $2 \mathrm{M} \mathrm{NaCl}$ was added slowly at room temperature for 4 times. The final concentration of $\mathrm{NaCl}$ was $0.3 \mathrm{M}$. The salt was used to block the negative charges on DNA strands to allow high density loading and rearrangement of DNA on AuNPs' surface. After incubation at room temperature for another $8 \mathrm{~h}$, the solution was centrifuged at 12,000 rpm for $20 \mathrm{~min}$. Then, the solution was purified through three times of centrifugation at 12,000 rpm for $20 \mathrm{~min}$. Finally, the AuNPs were resuspended in $20 \mathrm{mM}$ Tris- $\mathrm{HCl}(\mathrm{pH}$ 8.0) solution and stored at $4{ }^{\circ} \mathrm{C}$. The characterizations of probe 1 DNAmodified AuNPs were investigated by ultraviolet visible absorption spectroscopy (Fig. S1).

\section{Electrode treatment}

Pretreatment of gold electrode was according to our previous report [29]. The electrode was electrochemically activated in $0.5 \mathrm{M} \mathrm{H}_{2} \mathrm{SO}_{4}$. Probe 2 of $0.5 \mu \mathrm{M}$ was incubated with gold electrode for $12 \mathrm{~h}$ at room temperature. Then, the modified electrode was immersed into an aqueous solution of $1 \mathrm{mM}$ mercaptohexanol $(\mathrm{MCH})$ for $60 \mathrm{~min}$ to inhibit nonspecific DNA adsorption [30].

\section{Electrochemical measurements}

The target DNA was incubated with viral RNA at $90{ }^{\circ} \mathrm{C}$ for $5 \mathrm{~min}$ and dropped to room temperature slowly. After that, the reaction mixture was incubated with $1 \mu \mathrm{L}$ of $80 \mathrm{U} / \mu \mathrm{L}$ nuclease at $37^{\circ} \mathrm{C}$ for $30 \mathrm{~min}$. Then, the reaction mixture was placed at $90{ }^{\circ} \mathrm{C}$ for $15 \mathrm{~min}$ and annealed at $4{ }^{\circ} \mathrm{C}$. Then, the final reaction mixture was incubated with probe 2 -modified electrode. Finally, probe 1-functionalized AuNPs was incubated with the modified electrode for $2 \mathrm{~h}$. In this work, a threeelectrode cell was used with an $\mathrm{Ag} / \mathrm{AgCl}$ as the reference electrode, a platinum wire as the counter electrode, and a gold electrode as the working electrode. Two electrochemical techniques, linear sweep voltammetry and chronocoulometry, were conducted in the experiment. A Tris- $\mathrm{HCl}$ solution (pH 7.4) of $10 \mathrm{mM}$ containing $50 \mu \mathrm{M}$ RuHex and $10 \mathrm{mM}$ PBS buffer was used. The peak current at $-0.28 \mathrm{~V}$ was recorded and used to quantify the concentration of IBV H120 strain.

\section{Results and discussion}

\section{Working principle}

The detailed working principle is illustrated in Scheme 1. Herein, a label-free electrochemical assay based on equivalent substitution effect and AuNPs-assisted signal amplification is developed for identification and quantification detection of IBV H120 strain. We firstly design the H120 target DNA which can recognize RNA of H120 strain specifically, and the residual single-stranded H120 target DNA can be hydrolyzed by S1 nuclease. Then, the H120 target DNA is separated from the DNA-RNA hybridized double strand by heating. Thus, the concentration of virus RNA of H120 strain is equivalently substituted by the target DNA. The target DNA can partly hybridize with the probe 2 modified on the electrode surface and probe 1 on the surface of AuNPs. Due to an electrostatic interaction, positively charged signal molecules, hexaammineruthenium (III) chloride (RuHex), can be adsorbed onto the probe 1 modified on AuNPs which is pulled on the electrode surface through the target DNA, causing an intense electrochemical response. By analyzing the electrochemical response, a sensitive identification and quantification assay for IBV H120 strain is thus established and the method proposed in this work has a great potential for IBV detection in medical research and early IB diagnosis.

\section{Establishment and identification of standard plasmids}

As shown in Fig. 1a and b, electrophoresis results indicate PCR products of S1 gene are successfully amplified. Electrophoresis results of standard plasmids are shown in Fig. 1c. After being completely cleaved by EcoRI enzyme, two bands can be seen in the electrophoretic diagram that demonstrate the successful construction of plasmid.

\section{Determination of H120 strain concentration in real virus sample}

After construction of the standard plasmid containing characteristic sequence in $\mathrm{S} 1$ gene of H120 strain, virus copy numbers in plasmids are measured by real-time fluorescence quantitative PCR. Amplification and melting curve of plasmid in Fig. $2 a$ and $b$ indicate that there is no nonspecific amplification. A linear relationship between $\mathrm{Ct}$ value and the logarithm of the initial copy number of the standard plasmid (Fig. 2c) is obtained, and the linear regression equation is $Y=-$ $3.3191 \mathrm{x}+33.0203\left(R^{2}=0.99951\right)$. Thus, a series of H120 standard samples at different concentrations is successfully prepared for the following electrochemical detection. Meanwhile, according to calculation, the concentration of $\mathrm{H} 120$ virus sample is $1.56 \mathrm{e}^{-6} \mu \mathrm{M}(\mathrm{RSD}=0.67 \%, n=3)$. 
Scheme 1 Schematic illustration of the electrochemical method for IBV H120 strain detection

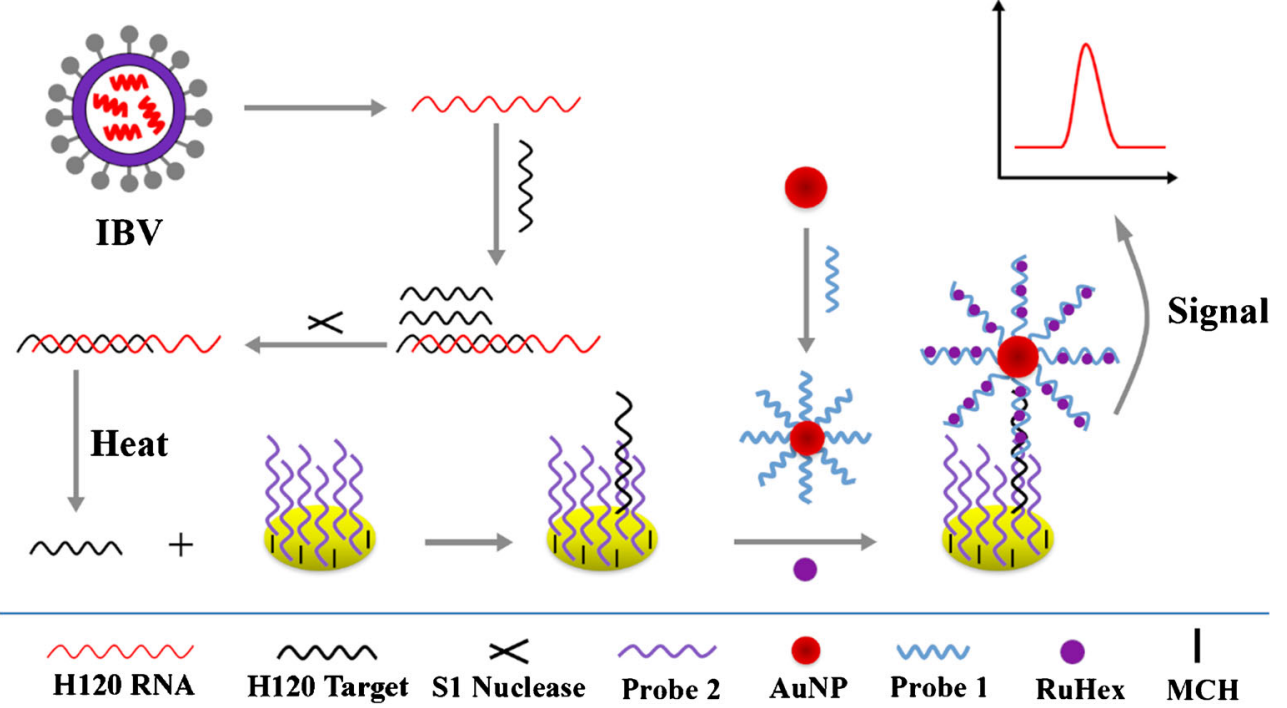

$3 \mathrm{c}$, the Tris- $\mathrm{HCl}$ buffer is better than PBS buffer. Therefore, the Tris- $\mathrm{HCl}$ buffer is chosen as the electrolyte.

\section{Electrochemical detection of IBV H120 strain}

The sensitivity of the sensing system is evaluated under the optimized experimental conditions. Firstly, we detect different concentrations of IBV H120 strain; a gradual increase of RuHex peak current corresponding with the elevated concentration of $\mathrm{H} 120$ strain from $1.56 \mathrm{e}^{-9}$ to $1.56 \mathrm{e}^{-6} \mu \mathrm{M}$ is obtained (Fig. 4a and b). And the peak current is linear with the logarithm of IBV H120 strain. The linear range of IBV H120 strain from $1.56 \mathrm{e}^{-9}$ to $1.56 \mathrm{e}^{-6} \mu \mathrm{M}$ with the detection limit at $2.96 \mathrm{e}^{-10} \mu \mathrm{M}$ is obtained $(\mathrm{S} / N=3, \mathrm{RSD}=1.65 \%, n=3)$. The linear regression equation is $Y=7.9821+0.6406 \mathrm{x}\left(R^{2}=\right.$ 0.99837 ), where $Y$ is the peak current and $x$ is the logarithm of IBV H120 strain concentration. To further evaluate the specificity of our proposed method, the chronocoulometry is used. We have detected H120 and NNA strain using H120 target DNA. As shown in Fig. 4c, NNA strain does not produce significant electrochemical signal and H120 strain could
Fig. 1 Agarose gel

electrophoresis diagrams. a Lane M: 2000 bp DNA marker, Lane 1 negative control, Lane 2: H120 S1 gene sample. b Lane M: 2000 bp DNA marker, Lane 1: negative control, Lane 2: NNA sample. c Lane M: $1 \mathrm{~kb}$ DNA Ladder marker, Lane 1: H120 plasmid, Lane 2: H120 plasmid is cleaved by EcoRI enzyme
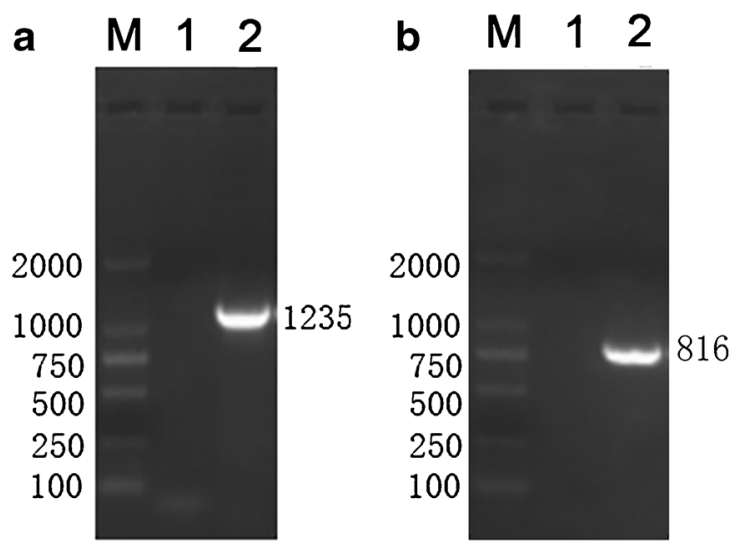
Fig. 2 Real-time fluorescence quantitative PCR plot. a Amplification plots. b Melting curves of $\mathrm{H} 120$ standard samples at $10^{2}, 10^{3}, 10^{4}, 10^{5}, 10^{6}, 10^{7}$, $10^{8}$, and $10^{9}$ copy numbers. $\mathbf{c}$ The linear relationship between $\mathrm{Ct}$ value and the logarithm of the initial copy numbers

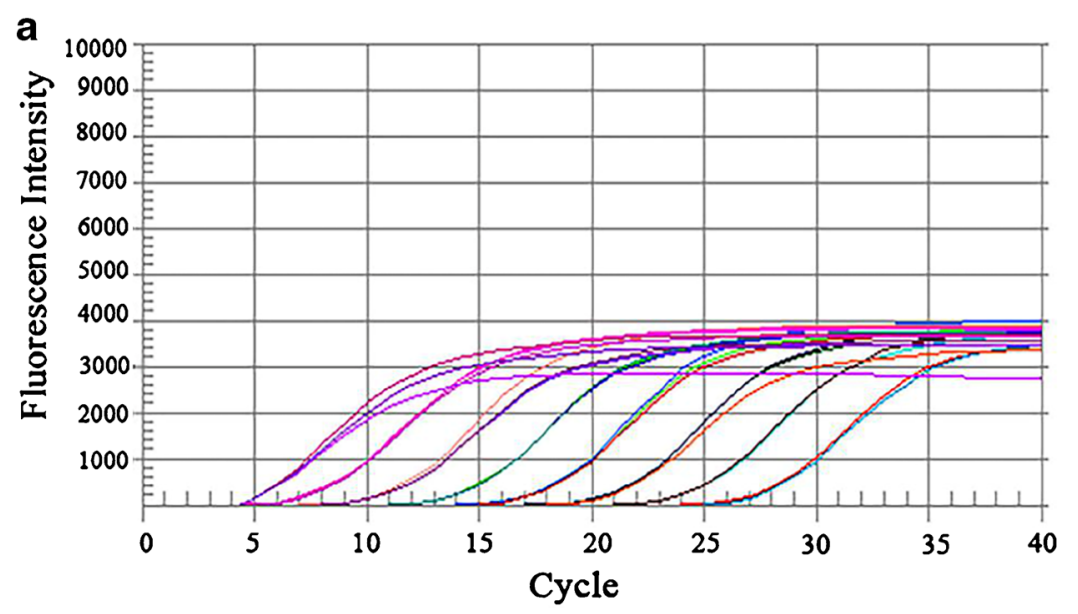

b

c

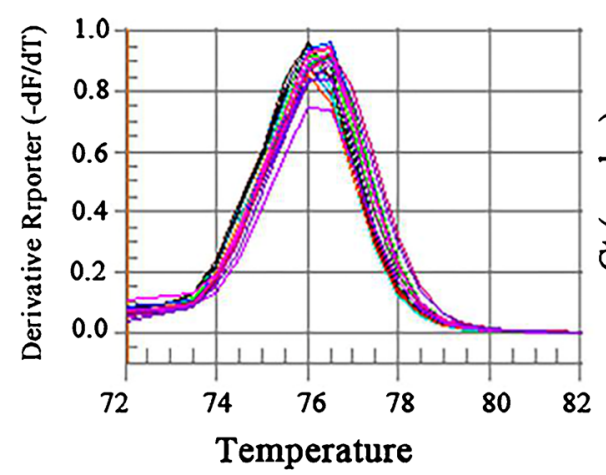

produce significant electrochemical signal, which signifies the excellent specificity of this method.

In order to evaluate the performance of the present sensor system, a comparable table for IBV analysis methods has been listed in the electronic supplementary material (Table S2). Though the construction of AuNPs is time-consuming and the introduction of the signal amplification makes the detection system a little bit complicated, it still can be seen from the table that our analysis method is more excellent than others due to the following attractive advantages. First, the IBV H120 strain RNA detection process is transformed into DNA detection which can effectively avoid RNA degradation.
Second, the use of gold nanoparticles greatly increases the electron transfer efficiency of electrode surface. Third, AuNPs-assisted electrochemical signal amplification highly enhances the sensitivity of IBV detection.

\section{Conclusions}

In this work, we designed the sequence of the target DNA based on the hypervariable region in the $\mathrm{S} 1$ gene between different IBV strains, then, constructed the standard plasmid containing characteristic sequence of S1 gene in H120 strain,
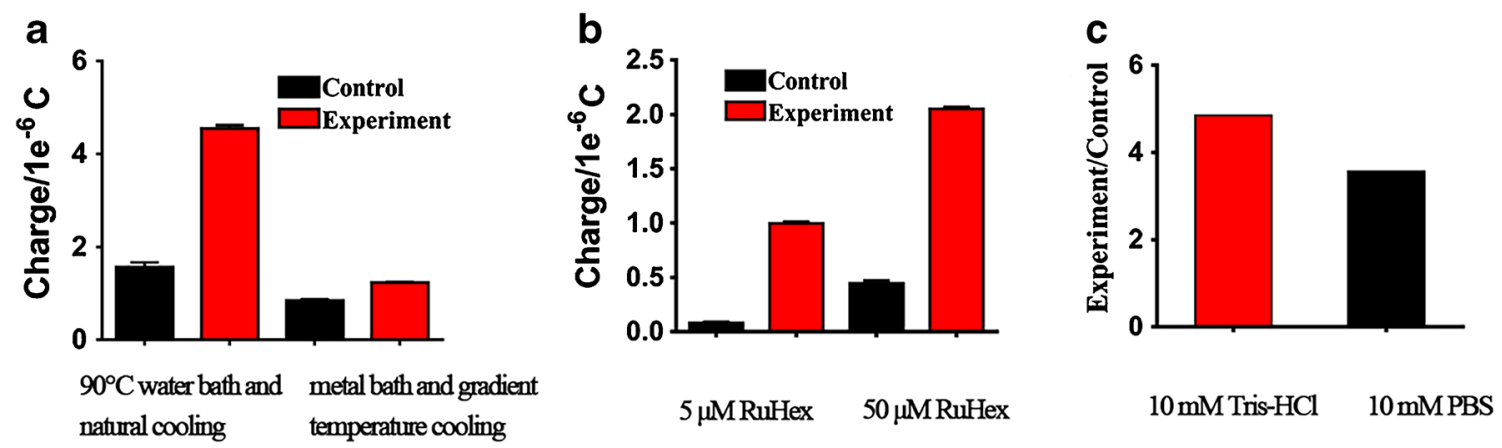

Fig. 3 Chronocoulometric-int numerical bar graph. a The annealing condition of target DNA and virus RNA. b The chronocoulometric response of RuHex. c The $\mathrm{pH} 7.0$ electrolyte 

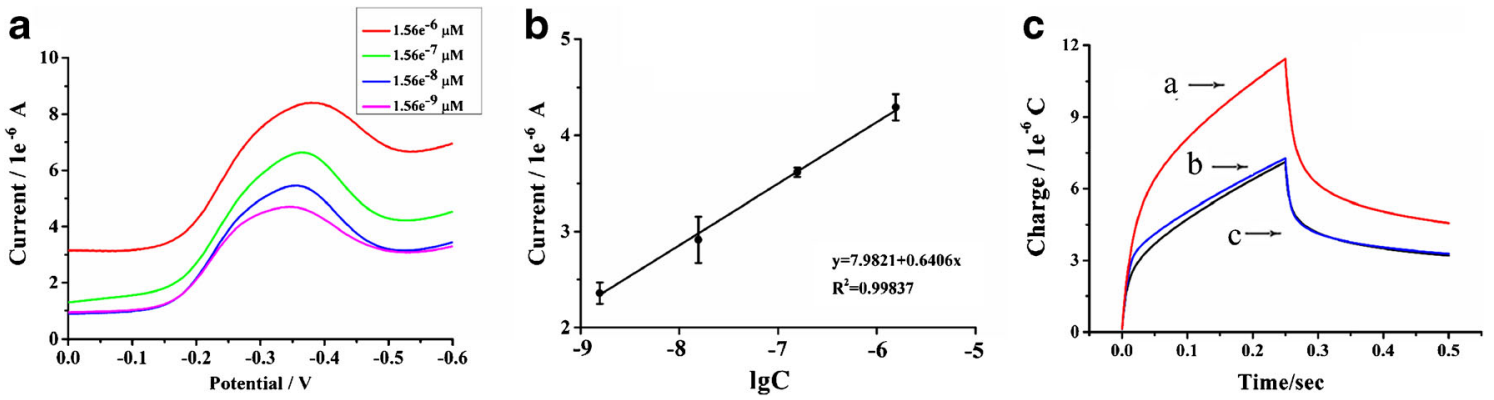

Fig. 4 Electrochemical detection of H120 RNA: a Linear sweep voltammetry corresponding to different concentration $\left(1.56 \mathrm{e}^{-9} \mu \mathrm{M}\right.$, $\left.1.56 \mathrm{e}^{-8} \mu \mathrm{M}, 1.56 \mathrm{e}^{-7} \mu \mathrm{M}, 1.56 \mathrm{e}^{-6} \mu \mathrm{M}, n=3\right)$. b The linear relationship

and at last, proposed a label-free ultrasensitive electrochemical assay applicable for the detection of IBV H120 strain in real sample, which can distinguish between H120 and NNA. In this electrochemical method, H120 strain detection is based on equivalent substitution effect and AuNPs-assisted signal amplification with a detection range from $1.56 \mathrm{e}^{-9}$ to $1.56 \mathrm{e}^{-6} \mu \mathrm{M}$. Compared with previously reported IBV detection methods that may focus on the portable and simplified analysis, our electrochemical assay still has some advantages. For example, converting RNA detection to DNA detection effectively avoid RNA degradation. The use of gold nanoparticles and AuNPsassisted electrochemical signal amplification greatly increases the electron transfer efficiency and the sensitivity of IBV detection. Furthermore, by analyzing the hypervariable region of S1 gene and replacing the target and probe DNA sequence by other customized sequences, the developed sensing strategy can be easily used to detect other virus. Therefore, the method might hold a great potential for further applications in virus bioanalysis, early clinical diagnosis, and biomedical research.

Acknowledgments The authors thank Merial Co. Ltd. (Nanjing, China) for providing IBV H120 and NNA strains.

Funding This research was funded by the Natural Science Foundation of Jiangsu Province for Excellent Young Scholars (BK20170087), the Fundamental Research Funds for the Central Universities (KYGD202001), the Key Project of Inter-governmental International Scientific and Technological Innovation Cooperation (2018YFE0102200), the Key Scientific and Technological Project of XPCC (2020AB025) and the Priority Academic Program Development of Jiangsu Higher Education Institutions (PAPD).

\section{Compliance with ethical standards}

Conflict of interest The authors declare that they have no conflict of interest.

\section{References}

1. Khan MZH, Hasan MR, Hossain SI, Ahommed MS, Daizy M (2020) Ultrasensitive detection of pathogenic viruses with between the peak current and the concentration of H120 RNA. c Chronocoulometric response of (a) $10 \mu \mathrm{L}$ H120 virus, (b) $10 \mu \mathrm{L}$ NNA virus, (c) $0 \mu \mathrm{L} \mathrm{H} 120$ virus

electrochemical biosensor: state of the art. Biosens Bioelectron 166:112431-112444

2. Ren G, Liu F, Huang M, Li L, Shang H, Liang M, Luo Q, Chen R (2020) Pathogenicity of a QX-like avian infectious bronchitis virus isolated in China. Poult Sci 99:111-118

3. Faruku B, Suri AS, Rahman OA, Hair BM, Salisu AM, Yusuf A (2016) Pathogenesis and diagnostic approaches of avian infectious bronchitis. Adv Virol 2016:1-11

4. Liu IL, Lin YC, Lin YC, Jian CZ, Cheng IC, Chen HW (2019) A novel immunochromatographic strip for antigen detection of avian infectious bronchitis virus. Int J Mol Sci 20:2216-2226

5. Lounas A, Oumouna BK, Medkour H, Oumouna M (2018) The first evidence of a new genotype of nephropathogenic infectious bronchitis virus circulating in vaccinated and unvaccinated broiler flocks in Algeria. Vet World 11:1630-1636

6. Nazmi A, Hauck R, Corbeil LB, Gallardo RA (2017) The effect of diatomaceous earth in live, attenuated infectious bronchitis vaccine, immune responses, and protection against challenge. Poult Sci 96: 2623-2629

7. Xu LW, Ren MT, Sheng J, Ma TX, Han ZX, Zhao Y, Sun JF, Liu SW (2019) Genetic and biological characteristics of four novel recombinant avian infectious bronchitis viruses isolated in China. Virus Res 263:87-97

8. Zhou Y, Yang X, Wang H (2016) The establishment and characteristics of cell-adapted IBV strain H120. Arch Virol 161:1-9

9. Vanbeurden SJ, Berends AJ, Kramer-Kuhl A, Spekreijse D, Chenard G, Philipp HC, Mundt E, Rottier PJM, Verheije MH (2018) Recombinant live attenuated avian coronavirus vaccines with deletions in the accessory genes $3 \mathrm{ab}$ and/or $5 \mathrm{ab}$ protect against infectious bronchitis in chickens. Vaccine 36:1085-1092

10. Valastro EC, Britton P, Fusaro A, Jackwood MW, Cattoli G, Monne I (2016) S1 gene-based phylogeny of infectious bronchitis virus: an attempt to harmonize virus classification. Infect Genet Evol 39:349-364

11. Akan M, Izgur M, Sareyyupolu B (2007) Diagnosis of infectious bronchitis in chickens by polymerase chain reaction and fluorescent antibody technique. Ank Univ Vet Fak Derg 54:47-54

12. Zhang DC, Long YQ, Li M, Gong JF, Li XH, Lin J, Meng JL, Gao KK, Zhao RL, Jin TM (2018) Development and evaluation of novel recombinant adenovirus-based vaccine candidates for infectious bronchitis virus and Mycoplasma gallisepticum in chickens. Avian Pathol 47:213-222

13. Ha-Jung R, Brian JJ, Deborah A, Hilt M, Jackwood W (2014) Detection ofinfectious bronchitis virus with the use of real-time quantitative reverse transcriptase-PCR and correlation with virus detection in embryonated eggs. Avian Dis 58:398-403

14. Cesewski E, Johnson BN (2020) Electrochemical biosensors for pathogen detection. Biosens Bioelectron 159:112214-112243

15. Zhang T, Chai H, Meng FY, Guo ZZ, Jiang Y, Miao P (2018) DNA-functionalized porous $\mathrm{Fe}_{3} \mathrm{O}_{4}$ nanoparticles for the 
construction of self-powered miRNA biosensor with target recycling amplification. ACS Appl Mater Interfaces 10:3679636804

16. Miao P, Zhang T, Xu JH, Tang YG (2018) Electrochemical detection of miRNA combining T7 exonuclease-assisted cascade signal amplification and DNA-templated copper nanoparticles. Anal Chem 90:11154-11160

17. Wang J, Yu J, Zhou XY, Miao P (2017) Exonuclease and nicking endonuclease-assisted amplified electrochemical detection of coralyne. Chemelectrochem 4:1828-1831

18. Jiang YT, Tang YG, Miao P (2019) Polydopamine nanosphere@ silver nanoclusters for fluorescence detection of multiplex tumor markers. Nanoscale 11:8119-8123

19. Pakchin PS, Ghanbari H, Saber R, Omidi Y (2018) Electrochemical immunosensor based on chitosan-gold nanoparticle/carbon nanotube as a platform and lactate oxidase as a label for detection of CA125 oncomarker. Biosens Bioelectron 122:68-74

20. Miao P, Tang YG, Wang BD, Jiang CM, Gao LQ, Bo B, Wang J (2016) Nuclease assisted target recycling and spherical nucleic acids gold nanoparticles recruitment for ultrasensitive detection of microRNA. Electrochim Acta 190:396-401

21. Bo B, Zhang T, Jiang YT, Cui HY, Miao P (2018) Triple signal amplification strategy for ultrasensitive determination of miRNA based on duplex specific nuclease and bridge DNA-gold nanoparticles. Anal Chem 90:2395-2400

22. Wang Q, Zou LY, Yang XH, Liu XF, Nie WY, Zheng Y, Cheng Q, Wang KM (2019) Direct quantification of cancerous exosomes via surface plasmon resonance with dual gold nanoparticle-assisted signal amplification. Biosens Bioelectron 135:129-136

23. Chen XF, Guo ZZ, Tang YG, Shen Y, Miao P (2018) A highly sensitive gold nanoparticle-based electrochemical aptasensor for theophylline detection. Anal Chim Acta 999:54-59

24. Zhao J, Zhu L, Guo C, Gao T, Zhu X, Li G (2013) A new electrochemical method for the detection of cancer cells based on small molecule-linked DNA. Biosens Bioelectron 49:329-333
25. Cao Y, Dai Y, Chen H, Tang Y, Chen X, Wang Y, Zhao J, Zhu X (2019) Integration of fluorescence imaging and electrochemical biosensing for both qualitative location and quantitative detection of cancer cells. Biosens Bioelectron 130:132-138

26. Nie J, Yuan L, Ke Jin K, Han X, Tian Y, Zhou N (2018) Electrochemical detection of tobramycin based on enzymesassisted dual signal amplification by using a novel truncated aptamer with high affinity. Biosens Bioelectron 122:254-262

27. Chen H, Sun X, Cai R, Tian Y, Zhou N (2019) Switchable DNA tweezer and G-quadruplex nanostructures for ultrasensitive voltammetric determination of the K-ras gene fragment. Microchim Acta 186:843-852

28. Xu YY, Lu CH, Sun YY, Shao YG, Cai Y, Zhang YS, Miao JF, Peng M (2018) A colorimetric aptasensor for the antibiotics oxytetracycline and kanamycin based on the use of magnetic beads and gold nanoparticles. Microchim Acta 185:548-556

29. Xu YY, Liu L, Wang ZY, Dai ZH (2016) Stable and reusable electrochemical biosensor for poly (ADP-ribose) polymerase and its inhibitor based on enzyme-initiated auto-PARylation. ACS Appl Mater Interfaces 8:18669-18674

30. Chai H, Xu JR, Xu JH, Ding SH, Tang YG, Miao P (2019) Star trigon structure-aided DNA walker for amplified electrochemical detection of DNA. Electrochem Commun 99:51-55

31. Weng X, Neethirajan S (2018) Immunosensor based on antibodyfunctionalized $\mathrm{MoS}_{2}$ for rapid detection of avian coronavirus on cotton thread. IEEE Sensors J 18:4358-4363

32. Ahmed SR, Kang SW, Oh S, Lee J, Neethirajan S (2018) Chiral zirconium quantum dots: a new class of nanocrystals for optical detection of coronavirus. Heliyon 4:1-17

Publisher's note Springer Nature remains neutral with regard to jurisdictional claims in published maps and institutional affiliations. 